Please cite this article as:

Kotzab, Herbert, Teller, Christoph, Grant, David B., Sparks, Leigh. 2011. Antecedents for the Adoption and Execution of Supply Chain Management. Supply Chain Management an International Journal, 16 (4), pp. 231-245, DOI 10.1108/13598541111139053. 
Herbert Kotzab $^{\text {I }}$, Christoph Teller ${ }^{\text {II }}$, David B. Grant ${ }^{\text {III }}$, Leigh Sparks ${ }^{\text {IV }}$

I, Department of Operations Management, Copenhagen Business School, 2000, Frederiksberg, Denmark, E-mail: hk.om@cbs.dk, Tel: 45 38152450; Fax: 45 38152440; Email: hk.om@cbs.dk;

II, corresponding author, Surrey Business School, University of Surrey, Guildford, GU2 7XH, England, United Kingdom; University of Stirling, Stirling. FK9 4LA. Scotland, United Kingdom; Email: c.teller@surrey.ac.uk;

III, Logistics Research Centre, Heriot-Watt University, Edinburgh, EH14 4AS, United Kingdom; Phone: +44 131451 3487, Fax: +44 131451 8336, Email: d.b.grant@hw.ac.uk;

IV, Institute for Retail Studies, University of Stirling; FK9 4LA Stirling, Scotland, United Kingdom, Tel: 44 (0) 1786467386; Fax: + 44 (0) 1786465290; E-Mail: leigh.sparks@stir.ac.uk; 


\title{
Antecedents for the Adoption and Execution of Supply Chain Management
}

\begin{abstract}
Purpose: The purpose of this paper is to develop a conceptual model that includes drivers of supply chain management (SCM) adoption and execution identified in the literature, provide a set of measurement scales that operationalise constructs within this model, empirically verify a hierarchical order of antecedents that affects the adoption and execution of SCM, and assist management by providing a focus on those SCM conditions and processes that need to be prioritised to increase successful SCM adoption and execution.
\end{abstract}

Design: The conceptual model is tested empirically through a survey of 174 senior supply chain managers representing the biggest organisations within a central European country.

Findings: Using structural equation modelling the hypothesised hierarchical order of three proposed antecedents are verified: 'internal SCM conditions' that affect 'joint or external SCM conditions' which in turn influences collaborative 'SCM-related processes'. Firms that adopt these steps should enjoy a rigorous and appropriate road to the full execution of SCM. Research limitations: The survey results reflect the views of large organisations in a countryspecific supply chain setting.

Practical implications: The findings provide a hierarchical focus for financial, personnel and management initiatives to increase integration within a supply chain and improve competitiveness.

Originality/value: The major contribution of this paper is that it provides empirical proof of the antecedents that affect the adoption and execution of SCM.

Keywords: Supply chain management, integration, antecedents, execution

Classification: Research paper 


\section{Introduction}

The concept of supply chain management (SCM) was introduced in the early 1980s (Harland, 1996). Since then, a substantial body of academic knowledge has been developed on this very broad topic. SCM is understood to be a set of practices for managing and coordinating the transformational activities from raw material suppliers to ultimate customers (Heikkilä, 2002). It has also been viewed as an organisational response by companies to pressures in their environment (Cravens et al., 1996). Finally, SCM considered is a long-term oriented, interfirm arrangement or alliance, involving intermediate or hybrid cooperative relationships (Das, 2006; Grant and Baden-Fuller, 2004).

Economic theory defines supply chains as multistage and multidirectional systems of autonomous decision makers. The set-up and management of such systems is the result of a social negotiation process among the interested parties regarding specific norms and standards (Halldorsson et al., 2007). As a result, close cooperation evolves as economically independent but otherwise mutually connected business entities seek to harmonise their individual courses of action. Such cooperation is based on strategically oriented trust alliances and is the result of an efficient division of labour and specialisation (Grant and Baden-Fuller, 2004; Das, 2006).

SCM therefore proceeds and develops through the systematic and strategic coordination of business functions and tactics within and across businesses, with an overall goal of improving the long-term profitability of all involved (Mentzer et al., 2001). It thereby integrates demand and supply management within and between companies (CSCMP, 2010).

Supply chains have of course long existed; for example the silk and spice caravans in the ancient world. However, in an organisational context SCM is a fairly recent phenomenon. 
Forrester noted in the mid-twentieth century that "management is on the verge of a major breakthrough in understanding how industrial company success depends on the interactions between the flows of information, materials, money, manpower, and capital equipment" (1958, p. 37). Yet, if management was ready to 'breakthrough' over fifty years ago, why did Mentzer et al. (2001) question the prevalence of SCM within firms at the start of the twentyfirst century? Despite claimed benefits, SCM execution appears to have lagged expectations.

Questions such as 'how does a firm and its management prepare to embrace (i.e. adopt) and implement (i.e. execute) SCM if it doesn't already do so?' or 'what are the barriers SCM faces and benefits it provides?' have not been satisfactorily addressed in SCM research (Stock et al., 2010). Based on this research gap we argue there a need to understand the antecedents required to adopt and execute SCM in order to academically and managerially comprehend the issues that must be considered and organised.

The aim of this paper is therefore to consider the antecedents and their relationships in the adoption and execution of SCM. The main finding comes in the identification that enterprises considering adopting SCM or inter-organisational integration i.e. having to look inwards first and prepare the organisation for SCM. While seeming intuitively obvious, this process has previously not been empirically confirmed. The value of this paper is that it represents the first attempt in measuring SCM adoption and execution; thereby providing an empirically validated measurement instrument. We thus provide both an academic and managerial contribution: We develop a conceptual model that includes drivers of SCM adoption and execution, provide a set of measurement scales that operationalise constructs within the model, empirically verify a hierarchical order of antecedents that affects the adoption and execution of SCM and assist practitioners by providing a focus on those SCM conditions and 
processes that need to be prioritised to increase SCM adoption and execution. In summary, we combine the consideration of antecedents as well as processes related to establishing SCM.

This paper consists of eight sections. After these introductory remarks we present and discuss how the existing literature has considered the issue of SCM adoption and execution. Subsequently, we identify direct and indirect antecedents of SCM adoption and execution in existing frameworks and propose a conceptual path model and related hypotheses. The empirical methodology that tests this conceptual model is then presented followed by our findings. The paper concludes by identifying the academic contribution and managerial implications, before addressing the limitations of the findings and avenues for further research.

\section{Issues in the Supply Chain Management Literature}

Embarking on a literature review of SCM is fraught with difficulty. On the one hand the broad approach to SCM encourages a rich and lively debate, but on the other hand leads to a fragmented literature with overlapping constructs and difficulty in producing consistent and generalisable findings (e.g. Stuart, 1997). SCM is both multidisciplinary and multifunctional and thus the domain of SCM research is fragmented, having been studied and commented upon from a wide range of academic disciplines and diverse theoretical perspectives (Cousins et al., 2006; Storey et al., 2006). There has been an 'explosion' of SCM interest across disciplines and journals, but multiple broad streams of research are developing relatively independently of each other and are not often comparable (Charvet et al, 2008). The diverse nature of SCM literature results from two factors (Lejeune and Yakova, 2005); it is at a confluence of many disciplines and also comprises different inbound and outbound entities operating at various stages in the supply chain. 
Croom et al. (2000) identified eleven subject areas considered core in the SCM literature. Their approach was adopted here in reviewing the literature to capture theoretical perspectives related to the research aims of this paper and found several overarching issues that inform this study.

First, many scholars have discussed the lack of a robust theoretical foundation in SCM or indeed a commonly-understood and applied definition. Several attempts have been made to address this challenge with varying degrees of success. However, there appears to be no universally-agreed unified theory of SCM (Halldórsson et al., 2007). The development of SCM has been largely practitioner-led, with theory (such as it is) largely following practice (Voss et al., 2002). The practical experience upon which this theory is based is often confined to a relatively small number of key industry sectors such as consumer goods retailing, computer assembling and automobile manufacturing (Kotzab and Otto, 2004; Burgess et al., 2006).

Second, there is evidence that the effective execution of SCM can result in improvements in the performance of firms. A study of almost 200 firms by Li et al. (2006) concluded that higher levels of SCM practice can lead to an enhanced competitive advantage and improved firm performance. Similarly, Frohlich and Westbrook (2001) investigated over 300 global manufacturers and found that firms with the widest supplier and customer integration had the highest rates of firm performance improvement. This is significant given the centrality of integration in SCM philosophy (Harland, 1996). 
However, Fabbe-Costes and Jahre (2008), in reviewing almost 40 academic articles on the subject of supply chain integration, noted that while over half of the articles concluded that integration has a positive effect on firm performance, caution is advised as there are a variety of empirical bases and research designs across the studies. Similarly, Storey et al. argued that "while there is an emerging body of theory which ostensibly offers a relatively coherent and compelling prescriptive narrative, predominant practice is at considerable odds with this conceptualisation" (2006, p. 755). This is confirmed by Fabbe-Costes and Jahre who note that "integration is more rhetoric than reality, that it might be more difficult in practice than in theory" (2007, p. 848).

Third, firms have not succeeded in implementing and mastering SCM (Chen and Paulraj, 2004). Turning the concept into practice is not easy and it has so far received more 'lip service' than accomplishment, except in a few leading edge companies (Leenders et al, 2002). The incorporation of SCM into the overall business planning process is not widely practiced (Carter and Narasimhan, 1994). Supply chain theory suggests that the chain should be managed from end-to-end, but Storey et al. (2006) found very little evidence for this notion.

Finally, Storey et al. (2006) raise doubts about claims that SCM advocates make regarding the 'discipline' of SCM and argue that the SCM literature tends "to move rather imperceptibly between description, prescription and trend identification" (p. 757). This results in normative tension between the is and the ought: "the rhetoric of managerial folklore tells managers to feel that they should take a broad, integrative approach and 'manage the whole chain', and this often clouds practitioner reports, with both overstatement and yet profound cynicism" (New, 1997, p. 16). 
Researchers in the area of SCM commonly agree on the positive effects of SCM on an organisation's performance. This is mainly due to the power enjoyed from the integration of business processes internally and externally. However, this agreement lacks empirical support as most research provides mostly anecdotal evidence. A substantive theoretical base for the establishment and execution of SCM is therefore lacking. There is a dearth of evidence in relation to the extent to which $\mathrm{SCM}$ - as defined in the academic literature - is implemented or even understood in practice. The literature does however provide some notions on the foundation of SCM based on conceptual models. These are examined in the next section.

\section{The Foundation of Supply Chain Management: Evaluation of Extant Frameworks}

The requirement for a firm to adopt and execute SCM stems from the marketplace, which expects both product and service customisation and optimal utilisation of resources in a global environment (Corbett et al., 1999; Christopher, 2000; Cousins and Menguc, 2006). The environment provides many organisations with an incentive to establish a value-added network, where complex inter-firm relationship management, collaboration and coordination takes place in the areas of product design, production, supplier selection and marketing (Cravens et al., 1996; Das, 2006; Cousins and Lawson, 2007).

However, with a few exceptions - Tarn et al. (2002) and Sridharan et al. (2005) - there has been a lack of research dealing with the question of how to achieve SCM within a firm, i.e. the adoption and execution of SCM. There are some frameworks in the literature which we now consider to determine commonality of constructs and underlying variables. Our intention form this exercise is to develop a theoretically-sound model addressing this adoption and execution gap. The literature was reviewed to determine the constitutional or antecedent elements of SCM adoption and execution. The hierarchical order in which these constitutional 
elements need to appear in a firm was also identified despite there being a lack of empirical evidence in the existing research.

Ten different frames of reference were identified developed by Bechtel and Jayaram (1997), Cooper et al. (1997), Lambert et al. (1998), Fawcett and Magnan (2001), Mentzer et al. (2001), Ho et al. (2002), Tan et al. (2002), Chen and Poulraj (2004), Cigolini et al. (2004), and Kotzab et al. (2006). Despite differences among these papers, all were constructed upon a basic idea that there are organisational and technical preconditions or antecedents for adopting joint business processes leading to the execution of SCM, both internally and with customers and suppliers. Table 1 compares these ten frameworks across the three dimensions of SCM: execution of SCM, the adoption of SCM processes, and antecedent SCM conditions.

\section{Insert Table 1 here}

Table 1 suggests that the elements found in the various frames support the classifications of Harland (1996) and Harland et al. (1999), namely that the level of integration amongst supply chain activities operates at four levels:

- Internal level; only those activities which are entirely internal to the focal company.

- Dyadic level; single two-party relationships between, for example, supplier and manufacturer or manufacturer and distributor/retailer.

- Chain level; a set of dyadic relationships including a supplier, a supplier's supplier, a customer and a customer's customer. 
- Network level; a wider network of operations.

SCM is thus considered as the integration of a firm's business processes, with the objective of replacing a single isolated operational unit with a whole supply chain spanning raw material suppliers to the ultimate customer (Frohlich and Westbrook, 2001; Heikkilä, 2002). Integration occurs in a forward as well as a backward direction (Cousins and Menguc, 2006). The aim of SCM business processes is to add customer value and to optimise the whole entity, instead of single parts (Cooper and Ellram, 1993; Cooper et al., 1997; Heikkilä, 2002). It is such business process integration that allows companies to exploit the advantages of SCM and thus achieve better performance by lowering costs and increasing profits and customer satisfaction (De Treville et al., 2004; Skjøtt-Larsen et al., 2005; Mitra and Singhal, 2008; Martinez-Sanchez et al., 2009).

We summarise the common denominators of all the frameworks examined in a conceptual model that consists of four latent constructs: 1) internal SCM conditions, 2) joint or external SCM conditions, 3) adoption of SCM-related processes and 4) execution of SCM.

SCM conditions are fundamental requirements for the adoption of SCM-related processes and the execution of SCM. They can be separated into internal and external or joint SCM conditions as shown in Table 2.

\section{Insert Table 2 here}


Internal SCM conditions are requirements for adopting SCM-related processes and executing SCM inside the organisation. They represent a commitment and dedication of human and financial resources, top management support, internal visions and goals, the staff's technical expertise, internal IT systems, guidelines for information exchange, education, the set-up of internal project groups and processes as well as integration behaviour (Bechtel and Jayaram, 1997; Cooper et al., 1997; Stuart, 1997; Lambert et al., 1998; Fawcett and Magnan, 2001; Mentzer et al., 2001; Grant and Baden-Fuller, 2004; Cigolini et al., 2004; Das, 2006; Cousins and Lawson, 2007; Martinez-Sanchez et al., 2009).

Joint or external SCM conditions are requirements for adopting SCM-related processes and SCM execution between organisations and in cooperation with partners in the supply chain. They include shared performance measurement, planning and controlling systems, shared vision and goals, organisational structure, joint project groups, systems perspective, trust, long-term-oriented relationships, power, shared profits and risks, mutual dependency, shared information on inventory status, shared information on forecasts, shared information on product development, organisational culture and equivalent management methods (Lambert et al., 1998; Ho et al., 2001; Mentzer et al., 2001; Tan et al., 2002; Chen and Poulraj, 2004; Harland et al., 2004; Cousins and Lawson, 2007; Das, 2006; Martinez-Sanchez et al., 2009).

SCM-related processes are those business practices that integrate or coordinate different key business areas within the firm and between a firm's suppliers and customers. They generate a flow of products, services and related information and create value for customers as well as improving the total performance of the chain (Fawcett and Magnan, 2001; Narasimhan and Das, 2001; Das et al., 2006; Martinez-Sanchez et al., 2009). These processes can be subdivided into eight areas: 1) customer relationship management, 2) customer service 
management, 3) demand management, 4) order fulfilment, 5) manufacturing flow management, 6) supplier relationship management, 7) product development and commercialisation and 8) returns management (Cravens et al., 1996; Cooper et al., 1997; Croxton et al., 2001; Lambert et al., 2005). Included in these processes are dimensions related to the customer and downstream and upstream product and information flows.

SCM execution within organisations is understood as the firm's internal and external integration of business processes with suppliers and customers to create value and to improve the total performance of the chain (Cravens et al., 1996; Cooper et al., 1997; Lambert et al., 1998).

Having established this framework for the antecedent conditions or elements in the adoption and execution of SCM, we now turn to developing our conceptual model and postulating related hypotheses, including proposed hierarchical levels, for empirical testing.

\section{Conceptual Model and Research Hypotheses}

The interrelation between the internal and the joint conditions suggests that 'homework' needs to be done internally in a company before concentrating on the external integration of business processes with suppliers and customers (Lambert, 2004). A comparison of different expectation levels between supply chain actors and partners regarding external integration performance has to be considered, as most SCM projects fail due to unbalanced output expectations (Lambert and Knemeyer, 2004). Lambert and Kneymeyer (2004) also presented the construct of organisational behaviour as a strategic component of SCM, including variables of culture, power and human resources. These prerequisites, which are needed to connect organisations within a network, were also considered by Mentzer et al. (2001). This 
issue of intra- and inter-company connectivity leads to the notion that SCM-related processes are affected by internal and joint conditions or antecedents (Lambert et al., 2005). This is in line with Grandori and Soda (1995) and Grandori (1997) and their stated importance for communication, rules and procedures as well as incentive systems for setting up interorganisational networks. Therefore, we hypothesise that:

\section{$\mathrm{H}_{1}$ : Internal SCM conditions positively impact joint SCM conditions.}

The lack of top management support, the inability to share information, a resistance to change, a lack of training and skills, a lack of process orientation, inflexible systems and processes, a lack of internal controlling systems, and no guidelines for information exchange are considered barriers that hinder the integration of business processes (Fawcett and Magnan, 2001; Narasimhan and Das, 2001; Droge et al., 2004; Das et al., 2006). To overcome these barriers, Bechtel and Jayaram (1997), Cooper et al. (1997) and Mentzer et al. (2001) suggest that firms should adopt internal education to develop a vision and to dedicate financial and human resources. For Droge et al. (2004), these are enablers for joint business processes and, following Lambert (1994), have to be operationalised first. Dyer and Nobeoka's (2000) development of knowledge-sharing processes between an organisation and its key suppliers, and Ebers and Grandiori's (1997) suggestion of how to configure flows of resources and information, concur with this position. Thus, we hypothesise that:

\section{$\mathrm{H}_{2}$ : Internal SCM conditions positively impact the adoption of SCM-related processes.}

\section{$\mathrm{H}_{3}$ : Joint SCM conditions positively impact the adoption of SCM-related processes.}


Joint conditions reflect a supply chain orientation that should lead to cooperation amongst three or more contiguous companies (Mentzer et al., 2001). Lambert et al. (2005) characterise this as the intra-company and inter-company connectedness that drives the degree of interorganisational interaction. It has also been shown by Auroja et al. (1999), Lamming (1993) and Sako (1992) that joint team working, sharing knowledge and expertise are indicative and necessary for managing inter-organisational relationships. Thus, we hypothesise that:

\section{$\mathrm{H}_{4}$ : Internal SCM conditions positively impact the execution of SCM.}

\section{H5: Joint SCM conditions positively impact the execution of SCM.}

SCM is executed by integrating corporate functions using business processes within and across companies (Lambert et al., 2005). This integration dimension is of strategic importance for managing supply chains (Frohlich and Westbrook, 2001). There are differences between no integration and a broad and narrow arc of integration between a focal company and its upstream and downstream stages. This arc of integration depends on the level of utilizing integrative processes internally and externally. Strategic alignment literature (e.g. Cousins and Menguc, 2006; Cousins and Lawson, 2007) notes that effective business process integration requires the joint alignment efforts of at least two actors leading to long-term, sustainable relationships, and gains arising from joint activities such as joint product development and integration of business processes. Thus, we hypothesise that:

\section{$\mathrm{H}_{6}$ : The adoption of SCM-related processes positively impacts the execution of SCM}

Figure 1 presents the conceptual model built upon the four major constituents or constructs: 
internal conditions, joint conditions, adoption of SCM processes and SCM execution, together with the hypotheses developed above.

\section{Insert Figure 1 here}

The overall research objective was to obtain a clearer understanding about which of the various condition and process-related variables have major significant impacts - indicated respectively by $\gamma$ parameters and hypotheses $\left(\mathrm{H}_{1}-\mathrm{H}_{6}\right)-$ on the degree of SCM execution in companies. A path model with the four constructs or latent variables was developed as depicted in Figure 1. $\xi_{1}$ (internal SCM conditions), $\xi_{2}$ (joint SCM conditions) and $\xi_{3}$ (adoption of SCM-related processes) can be regarded as exogenous or independent variables affecting the endogenous or dependent variable $\eta_{1}$ (execution of SCM). The arrows and the positive signs indicate the proposed direction of direct effects. Building on Lambert (2004), the intuitive model path would include $\gamma_{21}, \gamma_{32}$ and $\gamma_{13}$. However, the model also indicates that the execution of SCM may also be affected indirectly and independently by the two types of SCM conditions and therefore includes the proposed effects $\gamma_{31}$ and $\gamma_{32}$.

Finally, as noted above, internal and joint SCM conditions are antecedents of the adoption of SCM-related processes, which in turn affect the level of execution of SCM. Following New (1997) and New and Payne (1995), the development of the six hypotheses for testing also takes into account possible bypassing effects on SCM execution as represented by $\gamma_{11}$ and $\gamma_{12}$. To test the model an empirical study was designed; the research methodology is discussed next. 


\section{Methodology}

The methodology followed Churchill's (1979) two-stage development and validation of latent or unobservable and manifest or measurable constructs. This rigorous approach is suitable where phenomena are under-researched, as in this study, and is supported by two other, similar frameworks: Spector (1992) and Dunn et al. (1994). Content and substantive validity were checked via three qualitative interviews with experts from supply chain academia and practice. All the latent constructs are multi-faceted and were operationalised by a set of three or more indicators or manifest variables (see the Appendix for the item measures and the related literature).

The survey population consisted of 790 large Austrian companies in the retail and manufacturing sectors (ÖNACE classification $\mathrm{C}$ to $\mathrm{G}$ ); i.e. they have revenues greater than EUR 40 million and employees numbering more than 200. A random sample of 200 companies was drawn from this population and within those companies, senior managers responsible for logistics and SCM and representing one company in the sample, were identified and contacted personally. A self-administered questionnaire was sent to them after agreement in the pre-notification contact. This approach conformed to Dillman's (2007) tailored design method to ensure high response rates.

Due to the exhaustive pre-notification process 174 usable questionnaires were received, which represents a response rate of $87 \%$. Most respondents $(38.5 \%)$ represented manufacturing companies, followed by trading companies $(29.3 \%)$. The rest represented the service, building and energy sectors. In terms of location within their respective supply chains (multiple responses were of course possible), $33.6 \%$ were suppliers followed by $28.7 \%$ wholesalers, 
$20.2 \%$ original equipment manufacturers (OEMs), $10.9 \%$ retailers and $7.1 \%$ logistics service providers.

Most respondents (44.9\%) represented logistics and supply chain management departments in their organisations, while other departments represented included marketing and sales $(8 \%)$, procurement $(7.5 \%)$ and general management $(13.8 \%)$. The average employment duration of respondents with their company was 12 years (standard deviation $\sigma=11.6$ ). The average duration of the relationship of the organisation with their suppliers and customers was about 22.1 years $(\sigma=20.4)$.

Covariance-based structural equation modelling was used to test the model; comprehensive overviews of this analysis method can be found in Byrne (2001) and Shah and Goldstein (2006). First, bivariate correlations between all the indicators of each construct were calculated. All sets of indicators showed a high (Spearman's) $\rho$-value of around 0.85 , suggesting redundancy among some indicators. Redundant indicators were merged by calculating mean values (see the Appendix) and were thus combined into composite variables (Kline, 2005); this reduced the number of indicators for the four constructs reduced from 36 to 19 . This procedure resulted in a marginal loss of information, but substantially enhanced the parsimony of the model.

As a basic prerequisite, the local fit of the four measurement models were tested, i.e. the measurement validity and the global fit of the analyzed model and the degree of congruency between the proposed model and the empirical data. Suggestions from Churchill (1979) and Bagozzi and Yi (1988) were followed and confirmatory factor analyses for each of the measurement models were calculated. All constructs showed good internal consistency with 
Cronbach's or coefficient $\alpha$ around or above 0.70 (Fornell and Larcker, 1981). Indices showing the constructs' composite reliability $(\rho>0.60 ;$ AVE $>0.50)$ and discriminant validity $($ FLR $<1.0)$ also meet the recommended cut-off criteria (Bagozzi and Yi, 1988; Fornell and Larcker, 1981). Consequently, the local fit of the measurement models was regarded as satisfactory; all local fit measures are reported in the Appendix. Findings from the model testing are now discussed.

\section{Findings}

The global fit of the four latent constructs was tested by calculating and interpreting indices showing the absolute, incremental and parsimonious fit of each model (Anderson and Gerbing, 1988; Hu and Bentler, 1998, 1999). The modelling results are shown in Table 3. The caption at the bottom of the table includes the values of the single fit measures, which again meet recommended requirements. We thus consider the empirical data satisfactorily fits the proposed model.

\section{Insert Table 3 here}

The significant direct effects for the execution of SCM are shown in Table 3. The effects or standardised coefficients with significant $t$-values $(p<0.05)$ indicate whether the postulated hypotheses are accepted. The effect size or impact represented by the absolute value of the standardised path coefficients $(\gamma)$ is interpreted according to recommendations by Cohen (1988), where the impacts of factors are compared with each other. Values of less than 0.10 indicate low or marginal effects, values around 0.30 can be regarded as typical or medium 
effects and values above 0.50 are considered to be high or substantial.

As a result three hypotheses, $\mathrm{H}_{1}, \mathrm{H}_{3}$, and $\mathrm{H}_{5}$ are supported and the three related constructs are regarded as antecedents determining the level of execution of SCM in a direct way. The most substantial effect can be found between internal SCM conditions and joint SCM conditions $\left(\gamma_{21}\right)$. Neither of these two exogenous factors directly affect the execution of SCM to a considerable degree since $\gamma_{11}$ and $\gamma_{12}$ show no significant $t$-values $(p>.05)$; thus hypotheses $\mathrm{H}_{4}$ and $\mathrm{H}_{6}$ are not supported. Joint SCM conditions have a direct effect on the adoption of SCMrelated processes, which is also regarded as substantial $\left(\gamma_{32}\right)$. However, internal SCM conditions play no direct role major role in adoption $\left(\gamma_{31} ; \mathrm{p}>.05\right)$; thus hypothesis $\mathrm{H}_{2}$ is not supported. Finally, SCM-related processes turned out to be the only direct determinant of SCM execution having a direct and significant impact $\left(\gamma_{13}\right)$.

By additionally considering the indirect effects, i.e. effects mediated by either/or the factors $\xi_{2}$ and $\xi_{3}$, we found that all total effects, i.e. the sum of the direct and indirect effects on the execution of SCM, are significant. The internal SCM conditions, mediated by the joint conditions and the adoption of SCM-related processes, have the highest and thus most substantial impact on SCM execution. The joint conditions mediated by the adoption of SCMrelated processes also show a considerable total effect on SCM execution. This leads to a final conclusion that SCM conditions, although of no direct relevance, affect the overall execution of SCM very substantially.

The squared multiple correlation values $\left(r^{2}\right)$, which indicate the extent to which the variances of the factors $\xi_{2}, \xi_{3}$ and $\eta_{1}$ are explained by the proposed influencing constructs, were considerable. The $r^{2}$-values are above 0.50 for both the joint SCM conditions $\left(r^{2}=0.778\right)$ and 
the execution of SCM $\left(r^{2}=0.531\right)$, so more than $50 \%$ of the variance is explained by the influencing factors. However, more than $32 \%\left(r^{2}=0.325\right)$ of the variance of the adoption of SCM-related processes is accounted for by the influencing factors.

In summary, the model as postulated and tested is parsimonious and robust, allowing conclusions to be drawn.

\section{Conclusions}

In this paper, three constructs were identified at the firm level: internal conditions, joint or external conditions, and the adoption of SCM-related processes, that in turn affect a fourth construct of SCM execution. A conceptual model incorporating all four constructs was developed and tested in a quantitative empirical study. The model was developed from several extant frameworks in the literature and represents an initial attempt at identifying, setting-out and testing the various constructs and underlying variables and their hierarchical order.

The empirical findings confirmed the adoption of SCM-related processes as the core antecedent directly affecting SCM execution, thus supporting work of Lambert (2004). However, SCM conditions set up either internally or jointly play no significant role in changing the level of SCM execution directly, thus refuting notions of Cousins and Menguc (2006) and Das et al. (2006).

Joint or external SCM conditions, comprising both transactional- and relationship-related characteristics for supply chain partnerships, can be considered a second-order antecedent but a crucial prerequisite for adopting SCM-related processes. This finding is in-line with Droge et al. (2004) and Lambert (2004). In contrast, internal SCM conditions do not influence the 
adoption of SCM-related processes, but considerably and directly affect joint SCM conditions. This supports Mentzer et al. (2001) and Lambert (2004) regarding the necessity to ‘do the SCM homework’ first before entering into a supply chain partnership.

The results thus reveal a clear hierarchy of antecedents and thus our recommendations to organisations and managers intent on commencing SCM, and thus SCM partnerships, are to: 1) develop the organisation's own internal SCM conditions; then 2) work with external partners on developing joint SCM conditions both downstream (customers) and upstream (suppliers); before 3) adopting SCM-related processes thereby executing SCM and adopting a supply chain orientation.

This process supports our intuitively-proposed path model. While some might ask 'so what is new' we note that this model and its constituent elements have not been clearly identified or promoted previously in the wide and sometimes disparate literature regarding SCM. Thus, the theoretical and conceptual contribution from this work has been to properly identify, isolate and test these four constructs to determine this process flow. Firms adopting these steps in turn should thus be setting out on and following a rigorous and appropriate road to full SCM execution.

From a practical point of view, the results stress the importance for supply chain members to 'get their house in order' before thinking of or intensifying supply chain partnerships. Such a internal supply chain 'readiness' includes sufficient provision of human and financial resources as well as adequate IT-systems to facilitate and master SCM-relationships and data exchange. Further, the results also suggest providing proper information exchange guidelines and establishing internal SCM objectives that are crucial to enhancing the total level of SCM 
adoption and execution internally. Finally, 'soft' factors such as senior management support for and the propensity 'to do' supply chain management and the internal integration may be considered attributes to enhance the adoption and execution of SCM.

\section{Limitations and Further Research}

As with all research studies there are some limitations to this work. Firstly, the dependent construct of SCM execution and the independent construct of SCM adoption are explained only to a partial degree by the two independent constructs of internal and external conditions. This suggests that further research should extend the model to include other influencing factors reflecting 'soft' dimensions of supply chain partnerships, such as trust or power (Grant, 2005).

Secondly, the survey results reflect the views of large organisations in the Austrian market. Further research should extend the view towards smaller players and test the model with respect to their role in SCM partnerships, and also replicating the study in other countries and supply chain settings. Such research would help confirm the 'chain of effects' identified in our results.

Thirdly, a quantitative approach was applied in accordance with the research objectives and questions. Taking into account the shortcomings of survey approaches in general, a more indepth view may be obtained by investigating actual cases of the SCM execution. The quantitative results can be used as a basis (i.e. interview or discussion outline) for further indepth qualitative research intending to triangulate and confirm or adapt the proposed model for particular kinds of supply chain partnerships. 
Lastly, we exclusively investigated the effects between latent constructs according to our research aims and hypotheses. By conducting an importance performance analysis, as suggested by Johnson and Gustaffson (2000), the impact and relevance of each manifest variable behind our factors could also be tested.

\section{References}

Anderson, J.C. and Gerbing, D.W. (1988), "Structural equation modeling in practice: A review and recommended two-step approach", Psychological Bulletin, Vol. 103 No. 3, pp. 411-423.

Araujo, L., Dubois, A. and Gadde, L.E. (1999), "Managing interfaces with suppliers", Industrial Marketing Management, Vol. 28 No. 5, pp. 497-506.

Bagozzi, R.P. and Yi, Y. (1988), "On the evaluation of structural equation models", Journal of the Academy of Marketing Science, Vol. 16 No. 1, pp. 74-94.

Bechtel, C. and Jayaram, J. (1997), "Supply chain management: a strategic perspective", International Journal of Logistics Management, Vol. 8 No. 1, pp. 15-34.

Burgess, K., Singh, P.K. and Koroglu, R. (2006), "Supply chain management: a structured literature review and implications for future research", International Journal of Operations and Production Management, Vol. 26 No. 7, pp. 703-729.

Byrne, B.M. (2001), Structural Equation Modelling with AMOS: Basic Concepts, Applications, and Programming, Lawrence Erlbaum Associates, London.

Carter, J.R. and Narasimhan, R. (1994), "The role of purchasing and materials management in total quality management and customer satisfaction", International Journal of Purchasing and Materials Management, Vol. 30 No. 3, pp. 3-13.

Charvet, F.F., Cooper, M.C. and Gardner, J.T. (2008), “The intellectual structure of supply chain management: a bibliographic approach”, Journal of Business Logistics, Vol. 29 No. 1, pp. 47-74.

Chen, I.J. and Paulraj, A. (2004), "Understanding supply chain management: critical research and a theoretical framework", International Journal of Production Research, Vol. 42 No. 1, pp. 131-163.

Christopher, M.G. (2000), "The agile supply chain: competing in volatile markets”, Industrial Marketing Management, Vol. 29 No. 1, pp. 37-44.

Churchill, G.A. (1979), “A paradigm for developing better measures of marketing constructs", Journal of Marketing Research, Vol. 16 No. 1, pp. 64-73. 
Cigolini R., Cozzi, M. and Perona, M. (2004), "A new framework for supply chain management: Conceptual model and empirical test", International Journal of Operations and Production Management, Vol. 24 No. 1, pp. 7-41.

Cohen, J. (1988), Statistical Power Analysis for the Behavioral Sciences. Lawrence Erlbaum Associates, Hillsdale, NJ.

Cooper, M. C. and Ellram, L.M. (1993), "Characteristics of supply chain management and the implications for purchasing and logistics strategy", International Journal of Logistics Management, Vol. 4 No. 2, pp. 13-24.

Cooper. M.C., Lambert, D.M. and Pagh, J.D. (1997), "Supply chain management - more than a new name for logistics", International Journal of Logistics Management, Vol. 8 No. 1, pp. 1-14.

Corbett, C., Blackburn, J.D. and van Wassenhove, L. (1999), "Partnerships to improve supply chains", Sloan Management Review, Vol. 40 No. 4, pp. 71 -82.

Cousins, P.D. and Lawson, B. (2007), "Sourcing strategy, supplier relationships and firm performance: An empirical investigations of UK organizations", British Journal of Management, Vol. 18 No. 2, pp. 123-137.

Cousins, P.D. and Menguc, B. (2006), 'The implications of socialization and integration in supply chain management', Journal of Operations Management, Vol. 24 No.5, pp. 604-620.

Cousins, P.D., Lawson, B. and Squire, B. (2006), "Supply chain management: theory and practice - the emergence of an academic discipline?" International Journal of Operations and Production Management, Vol. 26 No. 7, pp. 697-702.

Cravens, D.W., Piercy, N.F. and Shipp, S.H. (1996), "New organizational forms for competing in highly dynamic environments: the network paradigm", British Journal of Management, Vol. 7 No. 3, pp. 203-218.

Croom, S., Romano, P. and Giannakis, M. (2000), "Supply chain management: an analytical framework for critical literature review", European Journal of Purchasing and Supply Management, Vol. 6 No. 1, pp. 67-83.

Croxton, K.L., Garcia-Dastugue, S.J., Lambert, D.M. and Rogers, D.S. (2001), “The supply chain management processes", International Journal of Logistics Management, Vol. 12 No. 2, pp. 13-36.

CSCMP (2010), CSCMP supply chain management definitions, http://cscmp.org/aboutcscmp/definitions.asp, viewed 07 October 2010.

Das, A., Narasimhan, R. and Talluri, S. (2006), 'Supplier integration - finding an optimal configuration", Journal of Operations Management, Vol. 24 No. 5, pp. 563-582.

Das, T.K. (2006), "Strategic alliance temporalities and partner opportunism”, British Journal of Management, Vol. 17 No., pp. 1-21. 
De Treville, S., Shapiro, R.D. and Hameri, A-P. (2004), "From supply chain to demand chain: the role of lead time reduction in improving demand chain performance", Journal of Operations Management, Vol. 21 No. 6, pp. 613-627.

Dillman, D.A. (2007), Mail and Internet Surveys: The Tailored Design Method, John Wiley and Sons, Hoboken (NJ).

Droge, C., Jayaram, J. and Vickery, S.K. (2004), "The effects of internal versus external integration practices on time-based performance and overall firm performance", Journal of Operations Management, Vol. 22 No. 6, pp. 557-573.

Dunn, S.C., Seaker, R.F. and Waller, M.A. (1994), "Latent variables in business logistics research: scale development and validation." Journal of Business Logistics, Vol. 15 No. 2, pp. 145-172.

Dyer, J. and Nobeoka, K. (2000), "Creating and managing a high performance knowledge, sharing network: The Toyota case”, Strategic Management Journal, Vol. 21 No. 3, pp. 345-367.

Ebers, M. and Grandori, A. (1997), "The forms, costs and development dynamics of interorganisational networking". Ebers, M. (Ed.), The formation of inter-organisational networks, Oxford University Press, Oxford, pp. 265-286.

Fabbe-Costes, N. and Jahre, M. (2007), "Supply chain integration gives better performance the emperor's new suit?" International Journal of Physical Distribution and Logistics Management, Vol. 37 No. 10, pp. 835-855.

Fabbe-Costes, N. and Jahre, M. (2008), "Supply chain integration and performance: a review of the evidence", International Journal of Logistics Management, Vol. 19 No. 2, pp. 130-154.

Fawcett, S.E. and Magnan, G.N. (2001), Achieving World-Class Supply Chain Alignment: Benefits, Barriers, and Bridges, Phoenix, National Association of Purchasing Management.

Fornell, C. and Larcker, D.F. (1981), "Evaluating structural equation models with unobservable variables and measurement error", Journal of Marketing Research, Vol. 18 No. 1, pp. 39-40.

Forrester, J.W. (1958), "Industrial dynamics: a major breakthrough for decision makers", Harvard Business Review, Vol. 36 No. (Jul.-Aug.), pp. 37-66.

Frohlich, M.T and Westbrook, R. (2001), "Arcs of integration: an international study of supply chain strategies", Journal of Operations Management, Vol. 19 No. 2, pp. 185200.

Grandori, A. (1997), "An organizational assessment of interfirm coordination modes", Organisation Studies, Vol. 18 No. 6, pp. 897-925.

Grandori, A. and Soda, G. (1995), "Inter-firm networks: Antecedents mechanisms and forms", Organisation Studies, Vol. 16 No. 2, pp. 183-214. 
Grant, D.B. (2005), "The transaction - relationship dichotomy in logistics and supply chain management", Supply Chain Forum: An International Journal, Vol. 6 No., pp. 38-48.

Grant, R.M. and Baden-Fuller, C. (2004), "A knowledge accessing theory of strategic alliances", Journal of Management Studies, Vol. 41 No. 1, pp. 61-84.

Halldórsson, Á., Kotzab, H., Mikkola, J.H. and Skjøtt-Larsen, T. (2007), “Complementary theories to supply chain management", Supply Chain Management: An International Journal, Vol. 12 No. 4, pp. 284-296.

Harland, C. (1996), "Supply chain management: relationships, chains and networks", British Journal of Management, Vol. 7 No. s1, pp. S63-S80.

Harland, C.M., Lamming, R.C. and Cousins, P.D. (1999), "Developing the concept of supply strategy", International Journal of Operations and Production Management, Vol. 19 No. 7, pp. 650-673.

Harland, C.M., Zheng, J., Johnsen, T. and Lamming, R. (2004), “A conceptual model for researching the creation and operation of supply networks", British Journal of Management, Vol. 15 No. 1, pp. 1-21.

Heikkilä, J., (2002), "From supply to demand chain management: efficiency and customer satisfaction", Journal of Operations Management, Vol. 20 No. 6, pp. 747-767.

Ho, D.C.K., Au, K.F. and Newton, E. (2002), "Empirical research on supply chain management: a critical review and recommendations", International Journal of Production Research, Vol. 40 No. 17, pp. 4415-4430.

Hu, L. and Bentler, P.M. (1999), "Cutoff criteria for fit indexes in covariance structure analysis: Conventional criteria versus new alternatives", Structural Equation Modeling, Vol. 6 No. 1, pp. 1-55.

Hu, L. and P.M. Bentler (1998), "Fit indices in covariance structure modelling: sensitivity to underparameterized model misspecification", Psychological Methods, Vol. 3 No. 4, pp. 424-453.

Johnson, M.D. and Gustafsson, A. (2000), Improving customer satisfaction, loyalty and profit, Jossey-Bass, San Francisco.

Kline, R.B. (2005), Principles and Practice of Structural Equation Modelling, Guilford Press, New York.

Kotzab, H. and Otto, A. (2004), "General process oriented management principles to manage supply chains. Theoretical identification and discussion", Business Process Management Journal, Vol. 10 No. 3, pp. 336 - 349.

Kotzab, H., Friis, A.and Busk, T. (2006), "The implementation of supply chain management within organizations: Construct, measurement and explorative empirical discussion", Die Unternehmung, Vol. 60 No. 2, pp. 89-104. 
Lambert, D. M., Garcia-Dastugue, S.J. and Croxton, K.L. (2005), “An evaluation of processoriented supply chain management frameworks", Journal of Business Logistics, Vol. 26 No., pp. 25-51.

Lambert, D.M. (2004), “The eight essential supply chain management processes”, Supply Chain Management Review, Vol. 8 No. 6, pp. 18-26.

Lambert, D.M. and M.A. Knemeyer (2004), "We're in this together", Harvard Business Review, Vol. 82 No. 12, pp. 114-122.

Lambert, D.M., Cooper, M.C. and Pagh, J.D. (1998), "Supply chain management: implementation issues and research opportunities", International Journal of Logistics Management, Vol. 9 No. 2, pp. 1-19.

Lamming, R.C. (1993), Beyond Partnerships: Strategies for Innovation and Lean Supply, Prentice-Hall London.

Leenders, M.R., Fearson, H.E., Flyn, A.E., and Johnson, P.F. (2002), Purchasing and Supply Management, McGraw-Hill, New York.

Lejeune, M.A. and Yakova, N. (2005), "On characterizing the 4 C's in supply chain management", Journal of Operations Management, Vol. 23 No. 1, pp. 81-100.

Li, S., Ragu-Nathan, B., Ragu-Nathan, T.S. and Subba Rao, S. (2006), “The impact of supply chain management practices on competitive advantage and organizational performance", Omega, Vol. 34 No. 2, pp. 107-124.

Martinez-Sánchez, A., Vela-Jiménez, M.J., Pérez-Pérez, M. and de-Luis-Carnicer, P. (2009), "Inter-organizational cooperation and environmental change: Moderating effects between flexibility and innovation performance", British Journal of Management, Vol. 20 No. 4, pp. 537-561.

Mentzer, J.T., DeWitt, W., Keebler, J.S., Soonhoong, M., Nix, N.C., Smith, C.C. and Zacharia, Z.G. (2001), "Defining supply chain management", Journal of Business Logistics, Vol. 22 No. 2, pp. 1-24.

Mitra, S., and Singhal, V. (2008), "Supply chain integration and shareholder value: Evidence from consortium based industry exchanges", Journal of Operations Management, Vol. 26 No. 1, pp. 96-114.

Narasimhan, R. and Das, A. (2001), "The impact of purchasing integration and practices on manufacturing performance", Journal of Operations Management, Vol. 19 No. 5, pp. 593-609.

New, S.J. (1997), “The scope of supply chain management research", Supply Chain Management: An International Journal, Vol. 2 No. 1, pp. 15-22.

New, S.J. and Payne, P. (1995), "Research frameworks in logistics: three models, seven dinners and a survey", International Journal of Physical Distribution and Logistics Management, Vol. 25 No. 10, pp. 60-77. 
Sako, M. (1992), Prices, Quality and Trust: Buyer Supplier Relationships in Britain and Japan, Cambridge University Press, Cambridge.

Shah, R. and Goldstein, S.M. (2006), "Use of structural equation modeling in operations management research: looking back and forward", Journal of Operations Management, Vol. 24 No. 2, pp. 148-69.

Skjøtt-Larsen, T., Schary, P., Mikkola, J. and Kotzab, H. (2005), Managing the Global Supply Chain. Copenhagen Business School Press, Copenhagen.

Spector, P.E. (1992), Summated Rating Scale Construction: An introduction (Series 07 Number 082), Sage, Newbury Park, CA.

Sridhanan, U.V., Caines, W.R. and Patterson, C.C. (2005), "Implementation of supply chain management and its impact on the value of firms", Supply Chain Management: An International Journal, Vol. 10 No. 4, pp. 313-318.

Stock, J.R., Boyer, S.L. and Harmon, T. (2010), "Research opportunities in supply chain management", Journal of the Academy of Marketing Science, Vol. 38 No. 1, pp. 3241.

Storey, J, Emberson, C., Godsell, J. and Harrison, A. (2006), "Supply chain management: theory, practice and future challenges", International Journal of Operations and Production Management, Vol. 26 No. 7, pp. 754-74.

Stuart, F.I. (1997), "Supply-chain strategy: Organizational influence through supplier alliances", British Journal of Management, Vol. 8 No. 3, pp. 223-236.

Tan, K.C., Lyman, S.B. and Wisner, J.D. (2002), "Supply chain management: a strategic perspective", International Journal of Operations and Production Management, Vol. 22 No. 6, pp. 614-631.

Tarn, M.J., Razi, M.A., Yen, D.C. and Xu, Z. (2002), "Linking ERP and SCM systems", International Journal of Manufacturing Technology and Management, Vol. 4 No. 5, pp. 420-439.

Voss, C., Tsikriktsis, N. and Frohlich, M. (2002), "Case research in operations management", International Journal of Operations and Production Management, Vol. 22 No. 2, pp. 195-219.

\section{Appendix}

\section{Insert Appendix here}


Figure 1: Conceptual model

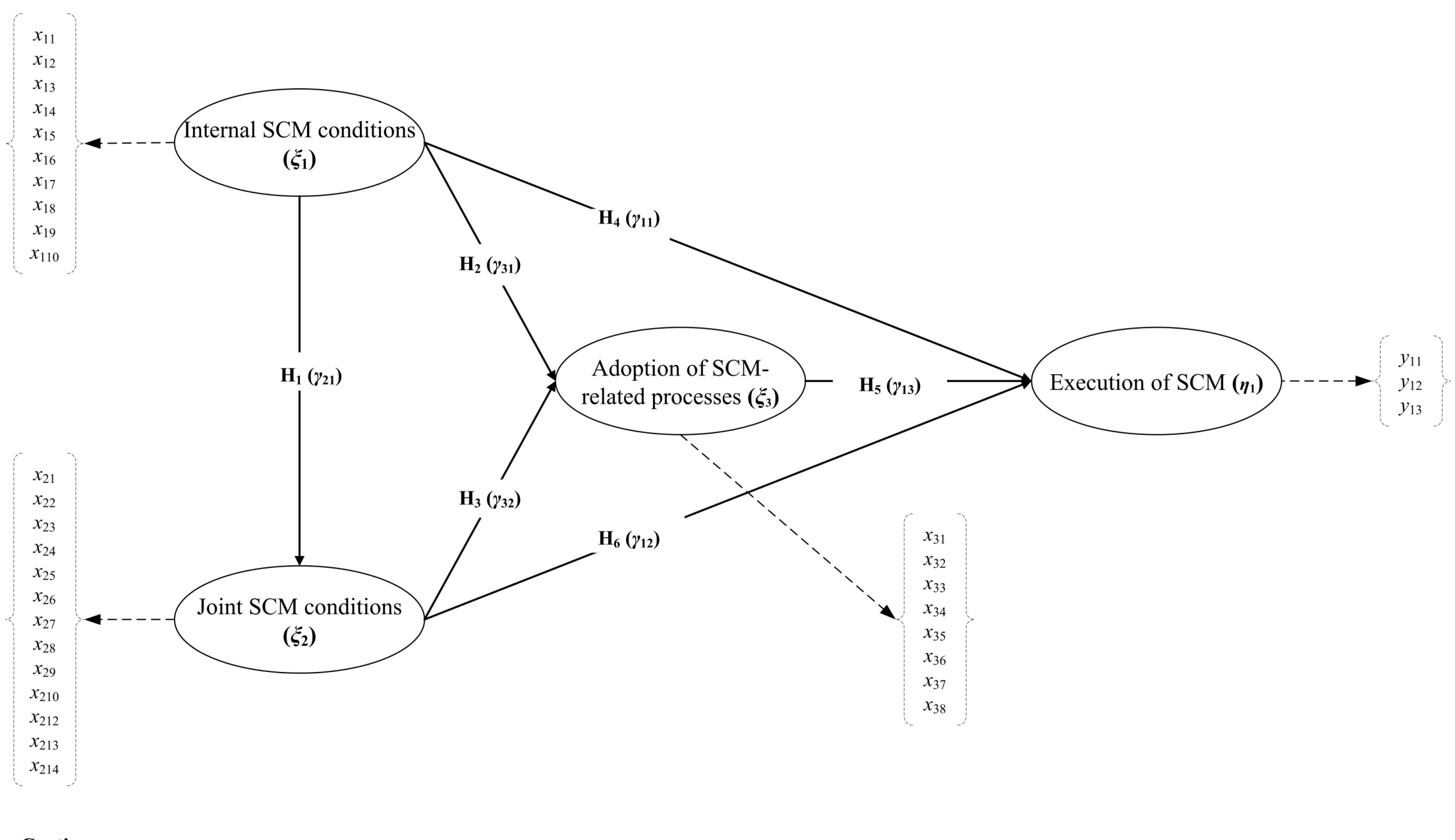

Caption:

$\xi_{\mathrm{n}}$, exogenous factors; $\eta_{1}$, endogenous factor; $\gamma_{\mathrm{n}}$, proposed effects, also indicated by the arrows and arrows heads; $x_{n}, y_{n}$, indicators, can be seen from the appendix; 
Table 1: Comparison of generic SCM frameworks

\begin{tabular}{|c|c|c|c|}
\hline Author(s) & Execution of SCM & SCM-related processes & SCM-related conditions \\
\hline $\begin{array}{l}\text { (I) } \\
\text { Bechtel and Jayaram } \\
(1997)\end{array}$ & $\begin{array}{l}\text {-- Chain of functions } \\
\text {-- Integration of processes } \\
\text {-- Flows of material and related information } \\
\text { Coordination of functions between ultimate } \\
\text { suppliers, focal company and ultimate } \\
\text { customers } \\
\text {-- Value adding for total chain } \\
\text {-- Relational factors }\end{array}$ & $\begin{array}{l}\text {-- Content areas } \\
\text { - Design } \\
\text { - Acquisition } \\
\text { - Storage } \\
\text { - Manufacturing } \\
\text { - Warehousing } \\
\text { - Distribution } \\
\text { - Installation } \\
\text { - Recycling } \\
\text { - Customer }\end{array}$ & $\begin{array}{l}\text {-- Process area Planning } \\
\text { - TQM - inter-organisational } \\
\text { relationships, processes, procedures, } \\
\text { tools, skills, organisational structure } \\
\text { - Systems thinking } \\
\text { - Cost analysis/Modelling } \\
\text {-Reengineering } \\
\text {-- Process area Execution } \\
\text { - Top management support } \\
\text { - Financial resources } \\
\text { - Technical expertise } \\
\text { - Staff to utilise } \\
\text {-- Process area IT } \\
\text { - Data storage } \\
\text { - Decision Support Tools } \\
\text { - Information transfer } \\
\text {-- Process area inter-organisational structure } \\
\text { measurement }\end{array}$ \\
\hline $\begin{array}{l}\text { (II) } \\
\text { Cooper et al. (1997) }\end{array}$ & $\begin{array}{l}\text {-- Integration of processes } \\
\text {-- Flows of material, services and related } \\
\text { information } \\
\text {-- Coordination of functions between ultimate } \\
\text { suppliers, focal company and ultimate } \\
\text { customers } \\
\text {-- Value adding for total chain }\end{array}$ & $\begin{array}{l}\text {-- Business Processes } \\
\text { - Customer Relationship Management } \\
\text { - Customer Service Management } \\
\text { - Demand Management } \\
\text { - Order Fulfillment } \\
\text { - Manufacturing Flow Management } \\
\text { - Procurement } \\
\text { Product Development and } \\
\text { Commercialisation } \\
\text { - Returns }\end{array}$ & $\begin{array}{l}\text {-- Network Structure } \\
\text { - Horizontal and vertical structure of the } \\
\text { chain } \\
\text { - The focal company's horizontal position } \\
\text {-- Management Components } \\
\text { - Physical and technical components - } \\
\text { planning and control methods; work } \\
\text { flow/activity structure; organisational } \\
\text { structure; communication and } \\
\text { information flow facility structure; } \\
\text { product flow facility structure } \\
\text { - Managerial and behavioural } \\
\text { components - management methods; } \\
\text { power and leadership structure; risk and } \\
\text { reward structure; culture and attitude }\end{array}$ \\
\hline
\end{tabular}




\begin{tabular}{|c|c|c|c|}
\hline $\begin{array}{l}\text { (III) } \\
\text { Lambert et al. (1998) }\end{array}$ & $\begin{array}{l}\text {-- Network Structure } \\
\text { - Horizontal and vertical structure of the } \\
\text { chain } \\
\text { - The focal company's horizontal position } \\
\text { - Process links across the supply chain } \\
\text {-- Management Components } \\
\text { - Physical and technical components - } \\
\text { planning and control methods; work } \\
\text { flow/activity structure; organisational } \\
\text { structure; communication and } \\
\text { information flow facility structure; } \\
\text { product flow facility structure } \\
\text {-- Managerial and behavioral components - } \\
\text { management methods; power and leadership } \\
\text { structure; risk and reward structure; culture and } \\
\text { attitude }\end{array}$ & $\begin{array}{l}\text {-- Integration of key business processes } \\
\text {-- Flows of material, services and related } \\
\text { information } \\
\text {-- Coordination of functions between ultimate } \\
\text { suppliers, focal company and ultimate } \\
\text { customers } \\
\text {-- Value adding for total chain }\end{array}$ & $\begin{array}{l}\text {-- Business Processes } \\
\text { - Customer Relationship Management } \\
\text { - Customer Service Management } \\
\text { - Demand Management } \\
\text { - Order Fulfilment } \\
\text { - Manufacturing Flow Management } \\
\text { - Supplier Relationship Management } \\
\text { - Product Development and } \\
\text { Commercialisation } \\
\text { - Returns Management }\end{array}$ \\
\hline $\begin{array}{l}\text { (IV) } \\
\text { Fawcett and Magnan } \\
(2001)\end{array}$ & $\begin{array}{l}\text {-- Collaborative effort of multiple channel } \\
\text { members to design, implement and manage } \\
\text { seamless value-added processes } \\
\text {-- Meet real needs of the end customer } \\
\text {-- Integration of people and technological } \\
\text { resources }\end{array}$ & $\begin{array}{l}\text {-- Implementation challenges } \\
\text { - Lack of top management support } \\
\text { - Non-aligned strategic and operating } \\
\text { philosophies } \\
\text { - Inability or unwillingness to share } \\
\text { information } \\
\text { - Lack of trust among supply chain } \\
\text { members } \\
\text { - Unwillingness to share risks and } \\
\text { rewards } \\
\text { - Inflexible organisational systems and } \\
\text { processes } \\
\text { - Cross-functional conflicts and "turf" } \\
\text { protection } \\
\text { - Inconsistent/inadequate performance } \\
\text { measures } \\
\text { - Resistance to change } \\
\text { - Lack of training for new mindset/skills }\end{array}$ & $\begin{array}{l}\text {-- Strategic management initiative } \\
\text { - Cross-functional process change } \\
\text { - Performance Measurement } \\
\text { - Alliance design } \\
\text { - Information Systems } \\
\text { - Alignment Mechanisms } \\
\text { - People environment }\end{array}$ \\
\hline $\begin{array}{l}\text { (V) } \\
\text { Mentzer et al. (2001) }\end{array}$ & $\begin{array}{l}\text {-- Coordination of functions between ultimate } \\
\text { suppliers, focal company and ultimate } \\
\text { customers } \\
\text {-- Value adding for total chain }\end{array}$ & $\begin{array}{l}\text {-- Supply Chain Orientation } \\
\text { - View of the coordination of a supply } \\
\text { chain from a system perspective } \\
\text {-- Antecedents } \\
\text { - Trust }\end{array}$ & $\begin{array}{l}\text {-- Functional Scope } \\
\text { - Marketing } \\
\text { - Sales } \\
\text { - Research and Development } \\
\text { - Forecasting }\end{array}$ \\
\hline
\end{tabular}




\begin{tabular}{|c|c|c|c|}
\hline & & $\begin{array}{l}\text { - Commitment } \\
\text { - Interdependence } \\
\text { - Organisational compatibility } \\
\text { - Vision and key processes } \\
\text { - Leadership } \\
\text { - Top management support } \\
\text {-- Organisational scope } \\
\text { - Integrated behavior } \\
\text { - Sharing information } \\
\text { - Shared risks and rewards } \\
\text { - Cooperation } \\
\text { - Similar customer service, goals and } \\
\text { focus } \\
\text { - Integration of key processes } \\
\text { - Long-term relationships }\end{array}$ & $\begin{array}{l}\text { - Production } \\
\text { - Purchasing } \\
\text { - Logistics } \\
\text { - Information Systems } \\
\text { - Finance } \\
\text { - Customer Service }\end{array}$ \\
\hline $\begin{array}{l}\text { (VI) } \\
\text { Ho et al. (2002) }\end{array}$ & $\begin{array}{l}\text {-- Management and integration of business } \\
\text { processes across the supply chain } \\
\text {-- Value creation } \\
\text {-- Collaboration }\end{array}$ & $\begin{array}{l}\text {-- Commitment } \\
\text {-- Joint actions/practices } \\
\text {-- Inter-organisational relationships } \\
\text {-- Inter-organisational economic behaviour } \\
\text {-- Inter-organisational cooperation } \\
\text {-- Trust } \\
\text {-- Power } \\
\text {-- Voluntary reciprocal engagement } \\
\end{array}$ & $\begin{array}{l}\text {-- Deliveries synchronisation } \\
\text {-- Integrated production planning, } \\
\text {-- Shared production forecasts } \\
\text { joint EDI access/networks } \\
\text {-- Packaging congruence } \\
\text {-- Kanban procurement approach }\end{array}$ \\
\hline $\begin{array}{l}\text { (VII) } \\
\text { Tan et al. (2002) }\end{array}$ & $\begin{array}{l}\text {-- Linking of all elements from the stage of raw } \\
\text { material through to end users } \\
\text {-- Total integration of all business entities } \\
\text {-- Encompassing organisational boundaries }\end{array}$ & $\begin{array}{l}\text {-- Commitment } \\
\text {-- Joint goal optimisation and efficiency }\end{array}$ & $\begin{array}{l}\text {-- Supply Chain Management practices } \\
\text { - Integration } \\
\text { - Information sharing } \\
\text { - Customer service management } \\
\text { - Geographical proximity } \\
\text { - Supply chain characteristics } \\
\text { - JIT-capability } \\
\text {-- Supplier evaluation practices } \\
\text { - Product and delivery assessment } \\
\text { - Capacity assessment } \\
\text { - Information assessment }\end{array}$ \\
\hline $\begin{array}{l}\text { (VIII) } \\
\text { Chen and Poulraj (2004) }\end{array}$ & $\begin{array}{l}\text {-- Development of collaborative advantage } \\
\text {-- Strategic vertical integration } \\
\text {-- Internal and external integration of business } \\
\text { processes }\end{array}$ & $\begin{array}{l}\text {-- Critical elements } \\
\text { - Trust and commitment } \\
\text { - Long term relations } \\
\text { - Cross-functional teams } \\
\text { - Communication }\end{array}$ & $\begin{array}{l}\text {-- Strategic purchasing } \\
\text {-- Supply Management } \\
\text { - Supplier selection } \\
\text { - Supplier involvement } \\
\text { - Supplier certification }\end{array}$ \\
\hline
\end{tabular}




\begin{tabular}{|c|c|c|c|}
\hline & & & $\begin{array}{l}\text { - Supplier base reduction } \\
\text {-- Logistics integration } \\
\text {-- Supply network coordination }\end{array}$ \\
\hline $\begin{array}{l}\text { (IX) } \\
\text { Cigolini et al. (2004) }\end{array}$ & $\begin{array}{l}\text {-- Process-oriented management approach to } \\
\text { sourcing, producing and delivering goods and } \\
\text { services } \\
\text {-- Cooperation and coordination of various } \\
\text { actors in a chain } \\
\text {-- Moving costs up- and downstream, increase } \\
\text { overall chain's profitability }\end{array}$ & $\begin{array}{l}\text {-- Supply chain Information tools } \\
\text { - Online connections (EDI, Internet, etc.) } \\
\text { for inter-company data transfer } \\
\text { - Automated identification systems } \\
\text { (barcodes, scanners, RFID, etc.) } \\
\text { - Integrated databases } \\
\text { - Direct knowledge of end demand } \\
\text {-- Supply chain coordination and control tools } \\
\text { - Supply Chain performance metrics } \\
\text { system } \\
\text { - Vendor rating systems } \\
\text { - Supply chain cost accounting system } \\
\text {-- Supply chain organisation tools } \\
\text { - Cross-firm incentive system } \\
\text { - Cooperation through interface } \\
\text { management }\end{array}$ & $\begin{array}{l}\text {-- Supply chain techniques related to the } \\
\text { configuration of the chain } \\
\text { - Design for SCM } \\
\text { - Warehouse network design } \\
\text { - Transportation fleet design } \\
\text { - Retailing system design } \\
\text { - Facilities network design } \\
\text {-- Supply chain techniques related to the } \\
\text { management of the chain } \\
\text { - JIT - Supply system } \\
\text { - Logistics category management } \\
\text { - Distribution alliances } \\
\text { - DRP } \\
\text { - Transport optimisation } \\
\text { - VMI } \\
\text { - Reserving upstream capacity or stock } \\
\text { - Reordering policies } \\
\text { - BPR } \\
\text { - Group purchasing }\end{array}$ \\
\hline $\begin{array}{l}\text { X) } \\
\text { Kotzab et al. (2006) }\end{array}$ & $\begin{array}{l}\text { Total internal integration of business processes } \\
\text { Total integration of business processes with } \\
\text { suppliers } \\
\text { Total integration of business processes with } \\
\text { customers }\end{array}$ & $\begin{array}{l}\text { - Internal SCM conditions } \\
\text { - Resource based conditions } \\
\text { - Integration based conditions } \\
\text { - Joint SCM conditions } \\
\text { - Decision based conditions } \\
\text { - Negotiation based conditions } \\
\text { - Mutuality and information based } \\
\text { conditions } \\
\text { - Organisational match based conditions }\end{array}$ & $\begin{array}{l}\text {-- Market oriented SCM-activities } \\
\text { - Product development and } \\
\text { commercialisation } \\
\text { - Returns } \\
\text { - CRM } \\
\text { - Procurement } \\
\text {-- Logistics oriented SCM-activities } \\
\text { - Order Fulfilment } \\
\text { - Demand Management } \\
\text {-Administrative processes }\end{array}$ \\
\hline
\end{tabular}


Table 2: Classification of antecedent conditions for adopting and executing SCM within organisations

\begin{tabular}{|c|c|c|c|c|c|c|c|c|c|c|}
\hline Internal SCM conditions (in alphabetical order) & (I) & (II) & (III) & $(\mathbf{I V})$ & $\begin{array}{c}\text { Publications } \\
(\mathrm{V})\end{array}$ & (VI) & (VII) & (VIII) & $(\mathbf{I X})$ & $(\mathbf{X})$ \\
\hline Commitment and dedication of resources & & & & & $\mathrm{x}$ & $\mathrm{x}$ & $\mathrm{x}$ & $\mathrm{x}$ & $\mathrm{x}$ & $\mathrm{x}$ \\
\hline Coordinated view & & & & & & & & & $\mathrm{x}$ & \\
\hline Cross-functional teams & & & & $\mathrm{x}$ & & & & $\mathrm{x}$ & $\mathrm{x}$ & $\mathrm{x}$ \\
\hline Guidelines for information transfer & $\mathrm{x}$ & & & & $\mathrm{x}$ & & & & & $\mathrm{x}$ \\
\hline Interdependency & & & & $\mathrm{x}$ & & $\mathrm{x}$ & & & $\mathrm{x}$ & \\
\hline Internal vision and goals & & & & & & & & & $\mathrm{x}$ & $\mathrm{x}$ \\
\hline Inter-organisational behavior & $\mathrm{x}$ & $\mathrm{x}$ & $\mathrm{x}$ & & & $\mathrm{x}$ & & & $\mathrm{x}$ & \\
\hline IT-systems & $\mathrm{x}$ & & & & $\mathrm{x}$ & & & & & \\
\hline Planning and control methods & $\mathrm{x}$ & $\mathrm{x}$ & $\mathrm{x}$ & $\mathrm{x}$ & $\mathrm{x}$ & & & & & $\mathrm{x}$ \\
\hline Staff's technical expertise/skills & $\mathrm{x}$ & & & $\mathrm{x}$ & & & & & & $\mathrm{x}$ \\
\hline Top Management support & $\mathrm{x}$ & $\mathrm{x}$ & $\mathrm{x}$ & $\mathrm{x}$ & & & & & $\mathrm{x}$ & $\mathrm{x}$ \\
\hline Willingness to share information & & $\mathrm{x}$ & $\mathrm{x}$ & $\mathrm{x}$ & & & & & $\mathrm{x}$ & \\
\hline \multicolumn{11}{|c|}{ External or joint SCM conditions (in alphabetical order) } \\
\hline Aligned strategic and operated philosophies & & & & $\mathrm{x}$ & & & & & & \\
\hline Communication & & $\mathrm{x}$ & $\mathrm{x}$ & & & & & $\mathrm{x}$ & & \\
\hline Culture and attitude & & $\mathrm{x}$ & $\mathrm{x}$ & & & & & & & $\mathrm{x}$ \\
\hline Inter-organisational/long-term relationships & & $\mathrm{x}$ & $\mathrm{x}$ & & & & & & $\mathrm{x}$ & \\
\hline Joint actions/practices & & & & & $\mathrm{x}$ & $\mathrm{x}$ & & & & $\mathrm{x}$ \\
\hline Joint goal optimisation & & & & & & & $\mathrm{x}$ & & & $\mathrm{x}$ \\
\hline Leadership & & $\mathrm{x}$ & $\mathrm{x}$ & & & & & & & $\mathrm{x}$ \\
\hline Management methods & & $\mathrm{x}$ & $\mathrm{x}$ & $\mathrm{x}$ & & & & & & \\
\hline Organisational structure and compatibility & $\mathrm{x}$ & $\mathrm{x}$ & $\mathrm{x}$ & $\mathrm{x}$ & & & & & $\mathrm{x}$ & \\
\hline Power & & & & & & $\mathrm{x}$ & & & & $\mathrm{x}$ \\
\hline Product flow facility & & & $\mathrm{x}$ & & $\mathrm{x}$ & & & & & \\
\hline Risk and reward structure/sharing risks & & $\mathrm{x}$ & $\mathrm{x}$ & $\mathrm{x}$ & $\mathrm{x}$ & & & & & $\mathrm{x}$ \\
\hline Systems thinking & $\mathrm{x}$ & & & $\mathrm{x}$ & & & & & $\mathrm{x}$ & $\mathrm{x}$ \\
\hline Trust & . & 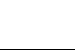 & & $\mathrm{x}$ & 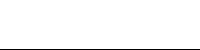 & $\mathrm{x}$ & 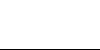 & $\mathrm{x}$ & $\mathrm{x}$ & $\mathrm{x}$ \\
\hline
\end{tabular}


Table 3: Antecedents of SCM adoption and execution

\begin{tabular}{|c|c|c|c|c|c|c|c|c|c|c|c|c|c|c|c|}
\hline \multirow[b]{2}{*}{ Exogenous factors } & \multicolumn{14}{|c|}{ Effects on factors } & External or Joint SCM conditions $\left(\xi_{2}\right)$ \\
\hline & & $\begin{array}{l}\text { Direct } \\
\text { cts }\left(\gamma_{n}\right)\end{array}$ & Med & $\begin{array}{l}\text { Indirect } \\
\text { effects }\end{array}$ & $\begin{array}{l}\text { Total } \\
\text { effects }\end{array}$ & & $\begin{array}{l}\text { Direct } \\
\text { fects }\left(\gamma_{n}\right)\end{array}$ & Med & $\begin{array}{l}\text { Indirect } \\
\text { effects }\end{array}$ & $\begin{array}{c}\text { Total } \\
\text { effects }\end{array}$ & & $\begin{array}{l}\text { Direct } \\
\text { ffects }\left(\gamma_{n}\right)\end{array}$ & Med & $\begin{array}{l}\text { Indirect } \\
\text { effects }\end{array}$ & $\begin{array}{c}\text { Total } \\
\text { effects }\end{array}$ \\
\hline $\begin{array}{l}\text { Internal SCM } \\
\text { conditions }\left(\xi_{1}\right)\end{array}$ & $\gamma_{11}$ & .252 & $\left\{\xi_{2}, \xi_{3}\right\}$ & .356 & $.608 * * *$ & $\gamma_{31}$ & -.139 & $\left\{\xi_{2}\right\}$ & $.606 * * *$ & $.467 * * *$ & $\gamma_{21}$ & $.881 * * *$ & $\{-\}$ & -- & $.881 * * *$ \\
\hline $\begin{array}{l}\text { External SCM } \\
\text { conditions }\left(\xi_{2}\right)\end{array}$ & $\gamma_{12}$ & .189 & $\left\{\xi_{3}\right\}$ & .280 & $.469 * *$ & $\gamma_{32}$ & $.688 * *$ & $\{-\}$ & -- & $.688 * *$ & -- & -- & $\{-\}$ & -- & -- \\
\hline $\begin{array}{l}\text { SCM-related processes } \\
\left(\xi_{3}\right)\end{array}$ & $\gamma_{13}$ & $.406^{* * *}$ & $\{-\}$ & -- & $.406 * * *$ & -- & -- & $\{-\}$ & -- & -- & -- & -- & $\{-\}$ & -- & -- \\
\hline
\end{tabular}

Notions: Table shows direct, indirect and total standardised effects (regression weights); global fit measures (recommended cut-off values in brackets): absolute fit measure: Root Mean Square Error of Approximation $(<.08)=.062$; incremental fit measures: Tucker-Lewis Coefficient/Comparative Fit Index (>.9/>.9)=.938/.947; parsimony fit measures: Normed $\chi^{2}(\mathrm{CMIN} / d f)(<3)=1.655$; degrees of freedom $(d f)=146$;

Caption: Med, mediators; *, $t$-values significant at $p<.05$ level (**, $p<.01$; ***, $p<.001)$; --, no (in)direct effect proposed or $\mathrm{n} / \mathrm{a}$; 


\section{Appendix}

\section{Factor}

Indicator ("to what degree...")

Measures/Indices

SCM conditions [Requirements which are the fundamental for originating SCM-related processes and the execution of SCM]

\section{Internal SCM conditions $\left(\xi_{1}\right)$}

$x_{11} \quad$... are personnel / human resources made available for SCM issues? ${ }^{\dagger(\mathrm{I})}$

$x_{12} \quad \ldots$ are financial resources made available for SCM issues? ${ }^{\dagger(\mathrm{I})}$

...does top-management of your company support SCM issues? ${ }^{\dagger(\mathrm{II})}$

$3.04(1.14)$

$2.87(1.14)$

$2.87(1.15)$

$3.13(1.23)$
$3.40(1.29)$

...were internal goals set up before SCM projects were launched? ${ }^{\dagger(\mathrm{II})}$

....are employees able to use IT-systems for SCM issues? ${ }^{\dagger(\mathrm{II})}$

$\begin{array}{lc}\text {...does your company have IT-systems capable of processing data from other SCM partners? }{ }^{\dagger(\mathrm{III})} & 3.12(1.30) \\ \ldots \text {... is there an agreement on guidelines with respect to the exchange of information with other companies } & 2.85(1.3)\end{array}$

$\rho / \alpha$

Literature

in the supply chain? ${ }^{\dagger(\mathrm{III})}$

$x_{18} \quad \ldots$ are employees trained in order to contribute to SCM-projects? ${ }^{\dagger(\mathrm{IV})}$

$x_{19} \quad$...does your company have project groups consisting of people from different functional areas? ${ }^{\dagger(\mathrm{VI})}$

$2.92(1.14)$

$3.26(1.28)$

...is there the necessary expertise in your company to set up and maintain supply chain relationships? ${ }^{\dagger(\mathrm{V})}$

...your company is willing to integrate with other supply chain members? 


\begin{tabular}{|c|c|c|c|c|}
\hline \multirow{2}{*}{\multicolumn{2}{|c|}{$\begin{array}{l}\text { Latent Dimension } \\
\text { Indicator ("to what degree...") }\end{array}$}} & \multicolumn{2}{|c|}{ Measures/Indices } & \multirow[t]{2}{*}{ Literature } \\
\hline & & $\mu(\sigma)$ & & \\
\hline \multicolumn{5}{|c|}{$\begin{array}{l}\text { SCM-related processes }\left(\xi_{3}\right) \text { [processes which integrate or coordinate different key business areas within } \\
\text { the firm and between a firm's suppliers and customers and create customer value] }\end{array}$} \\
\hline$x_{31}$ & $\begin{array}{l}\text {...is your company capable of processing orders according to agreement with customers in terms of } \\
\text { quantities and times? }\end{array}$ & $4.23(.77)$ & $\begin{array}{c}.75 / .74 \\
.51\end{array}$ & Lambert et al. (1997; 1998), \\
\hline$x_{32}$ & ...is your company capable of forecasting future customer demand? ${ }^{\dagger(\mathrm{XI})}$ & $3.37(.94)$ & & \\
\hline$x_{33}$ & ...is your company capable of adapting production capacity according to customer demand? ${ }^{\dagger(\mathrm{XI})}$ & $3.59(1.09)$ & & \\
\hline$x_{34}$ & ....is your company capable of informing customers about the current status of their orders? ${ }^{\dagger(\mathrm{XI})}$ & $4.02(1.02)$ & & \\
\hline$x_{35}$ & $\begin{array}{l}\text {...is your company capable of intergrating key accounts and suppliers into the product development } \\
\text { process? }\end{array}$ & $3.27(1.17)$ & & \\
\hline$x_{36}$ & ...is your company capable of dealing with returns and returned packaging? & $3.87(1.00)$ & & \\
\hline$x_{37}$ & $\begin{array}{l}\text {..is your company capable of intergrating key accounts in the development and implementation of } \\
\text { marketing programs? }\end{array}$ & $3.16(1.21)$ & & \\
\hline & ...is your company capable of building up multiple cooperations with important, strategic suppliers? & $3.75(1.02)$ & & \\
\hline \multicolumn{5}{|c|}{$\begin{array}{l}\text { The execution of SCM }\left(\eta_{1}\right) \text { [The firm's internal and external integration of business processes with } \\
\text { suppliers and customers which generates a flow of products, services and related information] }\end{array}$} \\
\hline$y_{11}$ & $\begin{array}{l}\text {...has your company integrated sourcing, logistics, marketing, product development and other areas } \\
\text { with your suppliers? }\end{array}$ & $2.84(1.11)$ & $\begin{array}{l}.79 / .78 \\
.56\end{array}$ & $\begin{array}{l}\text { Cooper et al. }(1997) \\
\text { Lambert et al. }(1998)\end{array}$ \\
\hline$y_{12}$ & $\begin{array}{l}\text {...has your company integrated sourcing, logistics, marketing, product development and other areas } \\
\text { with your customers? }\end{array}$ & $2.73(1.19)$ & & $\begin{array}{l}\text { Frohlich and Westbrook } \\
\text { (2001) }\end{array}$ \\
\hline$y_{13}$ & $\begin{array}{l}\text {..has your company internally integrated its sourcing, logistics, marketing, product development and } \\
\text { other areas? }\end{array}$ & $3.29(1.09)$ & & \\
\hline
\end{tabular}

Caption: $x, y$, indicator or manifest variable; $\xi$, $\eta$, factor or latent (endogenous) variable: $\mu$, mean value; $\sigma$, standard deviation; $\alpha$, Cronbach's Alpha; $\rho$, composite reliability; AVE, Average Variance Extracted; $\uparrow(\mathrm{I}-\mathrm{XI})$, summarised by calculating mean values because of high correlation between indicators (Spearman's $\rho$-value $>.85)$ and in order to decrease the degree of redundant information between indicators and increase of the parsimony of the model (Kline, 2005);

Notions: Ratings based on a 5-point scale, verbally and numerically anchored (1, to a very low degree; 5, to a very high degree); Cut-off values for measurement validity: $\alpha>.7 ; \rho>.6$; AVE>.5 (Fornell and Larcker, 1981; Bagozzi and Yi, 1988); sample size: $\mathrm{n}=174$; 